371.3::811.111'243

371.3::811.163.41'36

https://doi.org/10.18485/sj.2021.26.1.21

ДАНИЈЕЛА Г. КУЛИЪ

Универзитет у Приштини

са привременим седиштем у Косовској Митровици

Филозофски факултет

\section{ЈЕЛЕНА Д. МИХАЈЛОВИТ}

Универзитет у Приштини

са привременим седиштем у Косовској Митровици

Филозофски факултет
Оригинални научни рад

Примљен: 13. 10. 2020.

Прихваћен: 12. 1. 2021.

\title{
ПРИСТУПИ ОБРАДИ ГРАМАТИКЕ У НАСТАВИ СРПСКОГ КАО МАТЕРЊЕГ И ЕНГЛЕСКОГ КАО СТРАНОГ ЈЕЗИКА
}

Предмет истраживања у овоме раду јесу методички приступи који се примењују на часовима српског односно енглеског језика у основној и средњој школи. У првом делу рада контрастивним приступом се анализирају постојећи методички системи у настави матерњег и страног језика, док су у другом делу представљени резултати истраживања спроведеног међу студентима Катедре за српски језик и књижевност и Катедре за енглески језик и књижевност Филозофског факултета у Косовској Митровици о практичној примени различитих методичких система. Њихови ставови засновани су на искуству које су о приступима граматици стекли у току свог основношколског и средњошколског образовања, као и на основу теоријских сазнања која су стекли на часовима Методике наставе, у оквиру којих се организује и хоспитовање.

Кључне речи: граматика, методички приступи, традиционални приступ, индуктивно-дедуктивни приступ, савремени методички системи.

*danijela.kulic@pr.ac.rs 
Наставни процес је живи организам који се развијао кроз историју образовања, али се он и свакодневно мења у зависности од прописаних програма, задатих циљева, профила ученика/студената, тренутне популарности у примењеној лингвистици и/или наставној пракси која би требало да осликава статус и примену доминантне теорије учења и усвајања матерњег/страног језика. Када је реч о настави граматике српског као матерњег и енглеског као страног језика, методикама оба предмета су познати многи приступи овој апстрактној области који су у различитим периодима доминирали и утицали на развој свести о употреби граматике, како код наставника, тако и код ученика. Све методичке системе који се могу уочити у практичној настави Српског језика и књижевности и Енглеског језика грубо можемо поделити на две основне категорије - на традиционалне и савремене. С намером да се позитивна искуства из наставе матерњег језика пренесу на часове страног језика и обрнуто, контрастирали смо постојеће методичке системе у настави оба предмета, почев од најранијих, до новијих и најсавременијих. Резултати добијени на основу анализе постојеће литературе допуњени су квантитативним истраживањем које је спроведено међу студентима Катедре за српски језик и књижевност и Катедре за енглески језик и књижевност Филозофског факултета у Косовској Митровици. Питања, дата кроз анонимну анкету, односила су се на практичну примену различитих методичких система. Студенти су своје одговоре и ставове о изложеним проблемима заснивали на искуству које су о приступима граматици стекли у току свог основношколског и средњошколског образовања, као и на основу теоријских сазнања која су стекли на часовима методике наставе, у оквиру којих се организује и хоспитовање. Приликом анализе добијених одговора коришћена је метода квантитативне анализе, СПСС статистичка метода, док су одговори на питања отвореног типа анализирани дескриптивном методом.

У овој студији пресека учествовало је 48 студената завршне године на Катедрама за српски и енглески језик. Истраживање је обављено у мају 2019. године са циљем да се утврди следеће: а) у којој мери су студенти информисани о постојећим приступима обради граматике; б) њихови лични ставови о традиционалној и модерној настави граматике; в) могуће сличности и разлике у приступима граматици матерњег и страног језика како би се настава обају предмета унапредила захваљујући увтрђивању „пресека” ставова и мишљења до којих се дошло путем самоперцепције. 


\section{МЕТОДИЧКИ ПРИСТУПИ НАСТАВИ ГРАМАТИКЕ МАТЕРЬЕГ ЈЕЗИКА}

У настави граматике матерњег језика се, посматрано хронолошки, најраније јавио и најдуже задржао традиционални методички систем, односно његове различите варијанте (доминирао је наставом од почетка развоја школства све до последњих деценија двадесетог века), затим индуктивно-дедуктивни приступ, који се јавио као реакција на традиционалну наставу и, коначно, савремени методички системи, који, посматрани појединачно, имају одређене специфичности.

Један од првих традиционалних приступа језику Драгутин Росандић је назвао догматско-репродуктивним (1986: 767). О истом овом методичком систему у књизи Граматика у основној школи говорио је и Стјепко Тежак (1984: 50). Примена догматско-репродуктивног методичког система подразумевала је запамћивање знања строго у оном облику у коме су ученицима излагана (дакле, догматски), а потом и њихово дословно понављање (репродукцију). Доминација наставника у односу на ученике у овако организованом образовном процесу представљала је озбиљну сметњу интелектуалном развоју ученика и разумевању језичких појава и појмова.

Понављање и запамћивање дуго је пратило наставу граматике у основној школи. Неприхватљивост традиционалног начина рада водила је ка псеудоактивизацији ученика, која се такође дуго задржала у наставној пракси и постала доминантна карактеристика репродуктивно-експликативног система. Неколико новина је овакав приступ граматици у односу на догматско-репродуктивни учинило развијенијим; ипак, недовољно да би представљао значајнији напредак у развоју наставе граматике. Његово основно својство било је граматизирање и граматички вербализам.

Масовније пробијање система активне наставе у школску праксу одвијало се веома споро. Први корак који је водио ка напуштању система стицања знања утемељеног на вербалном преносу информација и њиховом понављању био је индуктивно-дедуктивни приступ граматици. ${ }^{1}$ Увођењем оваквог начина рада у наставу, ученици коначно постају активни учесници у наставном процесу. Овај методички систем име је добио на основу двеју метода које доминирају у његовој примени - метода индукције и дедукције. Као један од могућих приступа граматици постао је занимљив не само методичарима матерњег, већ и методичарима страних језика (в. Клозе 1953: 26). О индуктивно-дедуктивном путу у настави српског језика почело је да се говори и пише још четрдесетих година прошлог века. Мамузић је истицао да је половином прошлога века и у

${ }^{1}$ У литератури се за исти овај приступ граматици може наћи и термин аналитичко-експликативни. 
дидактичкој литератури и у школским књигама било „све више покушаја да се старо формално граматизирање замени једним поступком који не би оставио по страни ни ,језик” ни његову „стварност” (Мамузић 1965: 96). Међутим, и поред у то време честих констатација сличних Мамузићевој, главни део активности у настави граматике тек је требало да пређе на ученике, што се десило много касније, у последњим двема деценијама двадесетог века.

Након појаве индуктивно-дедуктивног приступа, као најзначајнија новина у развоју наставе граматике српског језика јавља се програмирана настава. То је први методички систем у оквиру кога ученици добијају знатно више могућности за индивидуални рад. „У систему програмиране наставе граматике неминовно је крајње индивидуално и самостално учениково кретање у процесу изучавања језичких појава" (Илић 1998: 506). Програмски приступ граматици се у методичкој литератури помиње већ неколико деценија уназад, али је доскора његова примена у пракси била права реткост. Узрок томе јесте чињеница да је програмирање наставних јединица веома комплексан процес, који, пре свега, подразумева стручност и информатичку писменост, а потом и креативност и амбициозност наставника.

У исто време када и програмирана настава, у методици наставе српског језика почињу да се помињу и други савремени методички системи, какви су проблемска настава, учење откривањем, асоцијативно учење, учење на погрешкама. За разлику од програмиране наставе, сви поменути приступи граматици темеље се на начелу стваралаштва ученика.

Доминантна црта проблемске наставе граматике јесте комбиновање поучавања и самоучења. Проблемска настава заснована је на тенденцији постепеног прерастања учења с туђом (наставниковом) помоћи у учење без туђе помоћи, те се сматра најуспешнијим начином оспособљавања ученика за самообразовање. Часови организовани на овај начин погодни су за примену како класичних облика рада, тако и за примену хеуристичког дијалога, групног облика рада, рада у паровима и индивидуализовану наставу (Михајловић 2019: 50-55).

Слична својства одликују и учење граматике откривањем. И приликом оваквог приступа граматици ученици су непрекидно интелектуално ангажовани, истичу питања, постављају и проверавају хипотезе, анализирају релевантне чињенице, откривају каузалне односе и за све тврдње траже убедљиве доказе. У учењу граматике на погрешкама код ученика се развија навика да на грешкама уче, уместо да их скривају. Грешке у овом методичком приступу заправо представљају полазни материјал од кога се креће у обраду нове наставне јединице. 
Проблемска настава, учење откривањем, асоцијативно учење и учење на погрешкама су методички приступи градиву из граматике који дају оптималне ефекте. Њима се остварују бројни образовни, васпитни и функционални циљеви, а коначна вредност огледа се у чињеници да се њиховом применом у пракси постиже највећа могућа активизација стваралачких снага ученика.

\section{НАСТАВА ГРАМАТИКЕ ЕНГЛЕСКОГ ЈЕЗИКА}

Као и у настави српског језика, и у настави енглеског граматика заузима важно, мада не и најважније место. Искуство са часова хоспитовања које се организује у оквиру Методике наставе енглеског језика показује да наставници у нашим школама и даље приоритет дају знању о језику, што би значило да се граматика у највећој мери предаје, тестира и оцењује. Разлоге за овакав преовладавајући однос наставника према граматици можемо само претпоставити: наставници предају онако како су њима предавали у школама; за припрему обраде граматичке јединице потребно је мање времена; вежбања већ постоје у уџбеницима, тако да припрема посебних вежбања и није неопходна. У теорији методике наставе енглеског језика граматика се изучава као само један од језичких система (Скривенер 2005, Ур 2000, Хармер 2007, Хеџ 2001). Поред граматике, наставни системи који се посебно изучавају су лексика, изговор и прагматика. Осим система, предмет изучавања методике наставе енглеског језика су и вештине, које се могу поделити на рецептивне (слушање и читање) и продуктивне (говор и писање).

Приступи обради граматичких јединица су варирали у зависности од актуелног метода/приступа. С краја деветнаестог и на почетку двадесетог века једини постојећи приступ био је граматичко-преводни, ${ }^{2}$ па се граматици приступало схоластички, правила и дефиниције су се училе напамет на матерњем језику, морфолошка и синтаксичка анализа на нивоу реченице биле су основа часова. С појавом директног метода, граматика остаје у фокусу, али се наставља традиција пуког меморисања правила и дефиниција на енглеском језику; експлицитно објашњавање је доминантна техника; анализа се врши на нивоу реченице. У оквиру аудио-лингвалног метода, граматичке структуре добијају још већу пажњу, с тим што се акценат ставља на коректност и увежбавање исправних исказа путем контролисаних вежбања како би се избегле грешке. Вежбање и презентовање граматичких јединица се обавља по утврђеном редоследу, док су понављања и имитација исправних исказа устаљене технике. Сви поменути методи у први план стављају граматичко металингвистичко знање, а занемарују употребу тог знања у конкретним ситуацијама у животу.

${ }^{2}$ Детаљан преглед метода и приступа учењу енглеског језика дат је у књизи Approaches and methods in language teaching, Richards, J. C and T. S. Rodgers, 1991, CUP. 
Тек са појавом функиионалног и комуникативног ${ }^{3}$ приступа превазилази се ниво реченице и граматичко знање почиње да се актуализује у конкретним дужим дискурсним јединицама. Приступ базиран на задатку (Вилис 1996) и когнитивни приступ (Крашен 1987: 132-134) конципирани су тако да се од ученика захтева максимално ментално ангажовање и способност решавања проблема логичким путем. Техника самооткривања, експлицитно и имплицитно усвајање и учење подједнако су заступљени и варирају у зависности од теме и задатка. Акценат у овим приступима није само на тачности, већ и на смислености и течности. Употреби граматике се посвећује подједнака пажња као и знању о граматици. У хуманистичком приступу граматика се посредно усваја кроз материјале и технике који су емотивно обојени (Московиц 1978).

Данас се у методици наставе страног језика, па и у настави граматике, препоручује комбиновање различитих приступа и метода, увођење техника којима се граматика усваја и учи, како експлицитно, тако и имплицитно. Хармер (1995) у својој књизи Teaching and Learning Grammar, посвећеној искључиво усвајању и учењу граматике, предлаже два основна начина презентовања, вежбања и тестирања знања из ове области: експлицитни (overt) и имплицитни (covert). Експлицитни начин приступању граматици подразумева углавном дедуктивно учење у којем се отворено презентују граматичке структуре, што укључује технике објашњавања облика и значења, приказивање употребе презентованих јединица уз мноштво примера у различитим ситуацијама. Имплицитно учење би одговарало индуктивном, у коме се за полазиште узимају примери, док се од ученика очекује да сами дођу до језичких законитости на основу датих узорака.

Без обзира на разноврсност програма који су данас на располагању наставницима и институцијама, у стварности су часови енглеског језика углавном базирани на граматичким програмима за које Нунан (1997: 28) каже да су најтипичнији били и остали. Они спадају у програме који су оријентисани ка производу, те за крајњи циљ имају одређена знања и вештине које би појединац требало да стекне као резултат инструкције. То су такви програми у којима је улазна информација (input) одабрана и градирана према граматичкој једноставности, односно сложености. Креатори оваквих програма занемарују чињеницу да граматичка сложеност није нужно изједначена с потешкоћама у учењу, односно, сложене граматичке јединице се често могу усвојити лакше и брже него једноставне и обрнуто. Према Нунану (1997: 29), претпоставка од које се полази у креирању граматичких програма је да се ,језик састоји од одређеног скупа правила која се могу комбиновати на различите начине како би се исказало значење". У пракси, савладавање граматике према оваквој

${ }^{3}$ О функционалном, комуникативном, приступу базираном на задатку, као и о осталим савременим приступима видети у Благојевић/Кулић (2013: 11-25). 
врсти програма одвија се тако што се на једном часу обрађује једна граматичка јединица; њој се поклања апсолутна пажња у смислу презентовања и контролисаног вежбања. Међутим, у оваквом приступу јавља се проблем јер је потребан шири језички контекст који не може бити градиран и апсолутно прилагођен нивоу знања ученика. Граматичка јединица која се обрађује на часу, према Крешену (1987: 21) „структура дана”, не би требало да буде посебно истакнута; напротив, ученицима би требало обезбедити разумљиву информацију која није прилагођена (roughly-tuned input) нивоу знања ученика. У складу с овом хипотезом, граматички аспекти само су интегрални део укупног садржаја којем су ученици изложени, за које се сматра да ће временом бити усвојени. Већина методичара који се баве усвајањем и учењем енглеског језика (Нунан 1997, Елис 2003, Хармер 1995, Хармер 2007, Скривенер $2005)$ данас критикује програме који су базирани првенствено на граматици, предлажући другачије, који инсистирају на смисаоној комуникацији у којој је форма подређена значењу. У оваквим програмима граматика је средство којим се постиже разумљива комуникација, она сама није циљ којем би требало стремити, већ је у служби разумљиве и смисаоне комуникације којом се задовољавају дискурсне језичке потребе.

\section{КОНТРАСТИРАњЕ МЕТОДИЧКИХ ПРИСТУПА У НАСТАВИ ГРАМАТИКЕ СРПСКОГ И ЕНГЛЕСКОГ ЈЕЗИКА}

Као наставни предмети, и Српски језик и књижевност и Енглески језик имају неке специфичности. Изучавање матерњег језика у школама подразумева упознавање ученика с његовим трима предметним подручјима, а то су језик, књижевност и језичко изражавање. У настави енглеског језика специфичност, пак, чини постојање четири наставна система (граматика, лексика, изговор и прагматика) и четири вештине (слушање, читање, говор и писање). Различито структурираним предметним и програмским целинама у једном и другом предмету узрокована је и различита ужестручна терминологија. Тако се у методици наставе српског језика за разнолике приступе обради граматике користе термини методички системи (Илић 1998: 493-517) и методички приступи, док се у методици наставе енглеског језика за то користе појмови методички приступи или само методи.

Како су разлике у структурисању предметних целина и стручној терминологији двају предмета евидентне, не можемо очекивати да се у практичној настави матерњег и страног језика примењују идентични приступи, методе и поступци. Ипак, дијахронијским прегледом раније примењиваних наставних система, као и оних који су у практичној настави језика тренутно актуелни, те њиховим контрастирањем, намеће се закључак да сличности има више 
него што се могло претпоставити. Подударања су нарочито изражена у традиционалним видовима наставе. Иако су се њихови називи разликовали, ${ }^{4}$ у време када су наставом доминирали традиционални методички системи, и на часовима једног и на часовима другог предмета доминирали су слични поступци: диктирање, понављање, запамћивање, учење правила и дефиниција напамет. Слично је било и у деценијама крајем двадесетог века, када је у настави Српског језика изразито било присуство индуктивно-дедуктивног методичког система, док је у настави Енглеског језика присутан био имплицитан и експлицитан начин усвајања градива, што управо одговара примени метода индукције и дедукције. Ситуација се променила, мада не значајно, последњих деценија. Иако се и данас у обемама методикама инсистира на истим задацима (односно функционалним знањима) и вредностима, поступци који карактеришу савремену наставу српског и енглеског језика се, поред многих подударности, и разликују, што свакако представља својеврсно дидактичко богатство које међупредметном корелацијом треба максимално искористити. Ty се, пре свега, мисли на преузимање методичких приступа који су својствени само једном предмету од стране наставника другог предмета и његово активно укључивање у постојећи наставни процес. Тако би се настава граматике српског језика могла значајно освежити и обогатити применом хуманистичког приступа, својственог настави енглеског језика, док би се настава енглеског језика, на пример, могла изводити и применом учења на погрешкама, које је типично за наставу српског језика.

\section{ИСТРАЖИВАЬЕ}

Истраживање које се односи на примену различитих методичких система у настави матерњег и страног језика спроведено је међу студентима српског и енглеског језика са Филозофског факултета у Косовској Митровици крајем маја 2019. године. У анонимном анкетирању учествовало је укупно 48 студената четврте године, од којих је 22 са Катедре за енглески језик, док 26 студената студира Српски језик и књижевност. Истраживањем су обухваћени студенти који су похађали часове методике наставе два семестра, у оквиру којих је организована и стручна пракса, односно посете школама где су студенти имали могућност да активно прате, анализирају и на крају школске године и сами изводе часове. У овој студији пресека испитана је самоперцепција студената у вези са наставом граматике матерњег и страног језика. Од испитаника се очекивало да на основу теоријског и практичног знања које су усвојили на

${ }^{4}$ У теорији методике наставе енглеског језика као традиционални методи помињу се граматичко-преводни, директни и аудио-лингвални метод, док су у настави матерњег језика то били догматско-репродуктивни и репродуктивно-експликативни методички системи. 
часовима методике, али узимајући у обзир и сопствено искуство које су стекли током читавог школовања, искажу свој став о понуђеним темама. Упитник се састојао од 16 питања, од којих је 14 питања затвореног типа, док су 2 питања отвореног типа. Одговори испитаника на питања затвореног типа обрађени су СПСС методом (дескриптивна статистика), док су одговори на питања отвореног типа анализирани дескриптивном методом.

\section{АНАЛИЗА РЕЗУЛТАТА}

Прва три питања у упитнику су фактичка и односе се на одсек на којем испитаници студирају, средњу школу коју су похађали и средину у којој се школа налази. На основу обрађених података целог узорка (48) који укључује обе студијске групе, дошло се до резултата да је већина студената завршила гимназију (43,8\%), те да велика већина $(95,8 \%)$ сматра да је граматика важан сегмент образовања. Средина у којој су испитаници завршавали средњу школу је углавном градска (87\%). На четврто питање које се односи на заступљеност граматике и књижевности у настави матерњег језика у основној школи, половина од укупног броја испитаника одговорила је да се већа пажња придавала граматици неголи књижевности (50\%).

У којој су мери наставници у основним и средњим школама били припремљени за наставу, какве су приступе користили, колико је савремена настава заживела у школама, какве поступке наставници предузимају, те да ли су у стању да повежу теоријско и практично знање, као и да лу спремни да се даље усавршавају, теме су о којима су испитаници износили своје ставове и мишљења.

\section{ПРИПРЕМЉЕНОСТ НАСТАВНИКА, ЗАСТУПЉЕНОСТ ПРИСТУПА И САВРЕМЕНА НАСТАВА ГРАМТИКЕ}

Одговори на питања (бр. 5 и 6) у вези са спремношћу наставника за часове граматике у основним и средњим школама указују на чињеницу да се наставници осредње припремају за поменуте обавезе, будући да је већина испитаника заокружила ову могућност (англисти 47,9\%, србисти 50\%). Мањи број сматра да су се наставници темељито припремали за наставу (англисти $31,3 \%$, србисти $35,4 \%$ ), док је најмање оних (14,6\% србиста и $20,8 \%$ англиста) који су мишљења да су се наставници недовољно припремали за часове.

Одговори на питања (бр. 7, 8, 9 и 10) у вези с врстом приступа који су примењивани на часовима граматике разликују се у зависности од одсека. Студенти српског језика су мишљења да је традиционални приступ градиву из 
граматике био заступљенији у основној школи неголи савремени (35,4\% према $2,1 \%$ ). Овај податак би, ипак, требало узети с резервом, јер 37,5\% испитаника са српске катедре није дало никакав одговор на поменуто питање. С друге стране, испитаници с Катедре за енглески језик у великој већини сматрају да је традиционални приступ био доминантан током њиховог основног образовања $(85,4 \%)$, док су савремени и хуманистички приступи били ретко примењивани.

Како испитаници перципирају наставу граматике у средњој школи, види се из резултата који говори у прилог чињеници да је традиционални начин презентовања и увежбавања граматичког градива доминантан у српском средњошколском образовању. Студенти српског језика сматрају да је традиционални приступ заступљенији у односу на остале понуђене (31,3\%), с тим што овај резултат такође треба узети с резервом јер ни на овом месту, као и код питања које се односило на основну школу, 35,4\% испитаника није дало никакав одговор. Да је комбиновани приступ учењу граматике уобичајен у средњој школи сматра 27,1\% студената Катедре за српски језик. С друге стране, студенти енглеског језика исказују другачији став у односу на своје колеге са српске катедре. Наиме, разултат је сличан као и у претходним питањима која су у вези с приступима у основној школи. Већина студената Катедре за енглески језик $(77,1 \%)$ мишљења је да је традиоционални приступ доминантан у средњој школи, док су остали наведени приступи, хуманистички и савремени, врло мало заступљени (10,4\% и $12,5 \%)$.

У упитнику је понуђено шест савремених приступа (техника) настави граматике који се користе у методикама обају предмета. ${ }^{5}$ На основу анализе података издвојила су се следећа три приступа/технике које би испитаници најрадије примењивали у свом раду: 1 . комуникативни $(68,8 \%), 2$. учење откривањем $(35,4 \%), 3$. интерактивно учење и персонализација $(29,2 \%)$. Проблемско учење $(18,8 \%)$ је за испитанике приступ чија је примена у настави граматике најмање адекватна. Овај податак изненађује с обзиром на чињеницу да се управо проблемско учење у теорији методике наставе матерњег и страног језика увек препоручује јер ученике ментално ангажује у правцу развоја њихових логичких способности без којих анализа и разумевање знања о језику (langue) competence) не би било могуће. Из ових одговора се може закључити да су испитаници склонији приступима који наглашавају спонтану интеракцију, лично укључење, самостално откривање и дешифровање језичких законитости. На основу резултата који су добијени може се закључити да је стицање знања језика (parole/performance) за испитанике важније од металингвистичког

${ }^{5}$ Овде постоји мимоилажење у терминолошком смислу јер су у настави енглеског језика асочијативно, проблемско, учење откривањем, персонализација и интеракиија заправо технике које се примењују у оквиру различитих приступа, док су индуктивно-дедуктивно учење (у енглеском , когнитивно”) и комуникативни приступ надређени појмови, представљају приступе, и обухватају поменуте и друге технике. 
знања граматике (познавање терминологије, способност стручног дефинисања језичких категорија и структура). У табели 1 дати су појединачни резултати изражени у процентима за цео узорак.

\section{Табела 1 - Савремни приступи у настави}

\begin{tabular}{|l|l|}
\hline Обе катедре & \\
\hline Индуктивно-дедуктивни приступ & $29,2 \%$ \\
\hline Комуникативни приступ & $68,8 \%$ \\
\hline Учење откривањем & $35,4 \%$ \\
\hline Асоцијативно учење & $22,9 \%$ \\
\hline Проблемско учење & $18,8 \%$ \\
\hline Интерактивно учење и персонализација & $29,2 \%$ \\
\hline
\end{tabular}

\section{ПОСТУПЦИ ИЗВОЪЕЊА НАСТАВЕ У САВРЕМЕНИМ МЕТОДАМА/ПРИСТУПИМА}

Анализом одговора на питања (бр. 11 и 12) која су у вези са поступцима које би испитаници применили у свом раду, добијени су резултати којима се потврђују претходни закључци. Наиме, највећи број испитаника је мишљења да би ученик требало да буде активни субјект у настави (95,8\%). С друге стране, пуко меморисање и репродуковање наставникових излагања је најмање популарна процедура међу испитаницима (6,3\%), што би значило да су испитаници врло свесни значаја активне улоге ученика у наставном процесу. Испитаници су, такође, свесни тога да је уочавање функције и значења језичких појава у настави граматике неопходно (72,9\%), те да би наставник требало да буде организатор у настави $(64,6 \%)$, односно да је његова одговорност значајан фактор у процесу усвајања и учења граматике матерњег и страног језика. Испитани студенти, затим, придају важност и менталним способностима ученика те њиховој вештини да сами уочавају и образлажу језичке појмове $(41,4 \%)$, чиме се потврђује чињеница да су самостално уочавање законитости и способност извођења закључака активности које би требало обавезно укључити у часове граматике. Испитаници су готово потпуно сагласни у томе да наставник не би требало да буде у центру пажње, а да ученикова улога не би смела да буде улога пасивног слушаоца. Из ових резултата се може видети да је свест студената, будућих професора, о улогама наставника и ученика у великој мери развијена, те да би се велика већина определила за пристуn $y$ 
чијем центру пажње је ученик. Појединачни резултати за сваки од поступака који се примењују у оквиру савремених метода/приступа дати су у табели 2.

\section{Табела 2 - Поступии неопходни за извођење наставе}

\begin{tabular}{|l|l|}
\hline Обе катедре & \\
\hline У центру пажње је наставник. & $8,3 \%$ \\
\hline Ученик сам уочава и образлаже језичке појаве. & $41,7 \%$ \\
\hline Наставник предаје о језичким појавама и појмовима. & $31,3 \%$ \\
\hline Ученик је пасивни слушалац. & $6,3 \%$ \\
\hline Ученик је активни субјект. & $95,8 \%$ \\
\hline Наставник је организатор. & $64,6 \%$ \\
\hline Врши се индивидуализација наставе. & $20,8 \%$ \\
\hline Уочавају се функција и значење језичких појава. & $72,9 \%$ \\
\hline Ученик механички памти и репродукује наставникова излагања. & $6,3 \%$ \\
\hline
\end{tabular}

\section{ПОВЕЗИВАЮЕ ТЕОРИЈЕ И ПРАКСЕ}

Када је у питању однос теорије и праксе (питање бр.13), већина испитаника сматра да наставници само делимично успевају да повежу теоријска сазнања са практичним радом у школама $(60,4 \%)$. Став да наставна пракса прати теоријска сазнања изнело је $27,1 \%$ испитаних, док $10,4 \%$ сматра да се у наставној пракси углавном одступа од теорије. Опште је веровање да наставници, једном када заврше студије и формално образовање, престају да се интересују за новине и промене које предлажу „теоретичари”, углавном запослени на факултетима и институтима за језик. На основу овог резултата можемо претпоставити да је веза између практичара, тј. наставника који раде у школама и теоретичара, који се баве научним радом и истраживањима веома слаба, те да је потребно пронаћи нове начине сарадње између ове две групације у образовању.

\section{УЛОГА СЕМИНАРА И ПРЕДЛОЗИ СТУДЕНАТА ЗА ОСАВРЕМЕЊИВАЮЕ НАСТАВЕ ЈЕЗИКА}

Више од половине испитаника (58,3\%) сматра да су семинари које организује Министарство просвете користан начин да се унапреди пракса у настави 
матерњег и страног језика. Управо путем семинара долази до повезивања не само теоријских и практичних сазнања, већ је то прилика да колеге међусобно размењују искуства и унапређују своје часове. Да су семинари потпуно неважни у наставничкој професији, сматра само 2,1\% испитаника, док се 37,5 \% студената делимично слаже са оваквим активностима у унапређењу наставне праксе у области матерњег и страног језика.

На питања отвореног типа која се тичу начина на које се настава енглеског језика може осавременити, испитаници су наводили следеће предлоге: побољшање физичких услова и увођење визуелних средстава попут слика, мапа, цртежа; употреба интернета, филмова, блогова, музике; усавршавање наставника кроз семинаре и радионице; укључење аутентичних материјала и изворних говорника; слободна конверзација и дискусије на енглеском језику; обрада актуелних тема; подизање свести наставника и ученика у вези са савременим приступима и добробитима које они доносе.

Студенти Катедре за српски језик и књижевност такође сматрају да је наставу неопходно освежити коришћењем савремене технологије, да школе треба опремити специјализованим учионицама, док појединци сматрају да бољем квалитету часова знатно доприноси добро припремљена уводна мотивација, прилагођена узрасним могућностима ученика, те да би за ученике било корисно да се у пракси користе и примери језика из свакодневних говорних ситуација које су им блиске и доживљене, што свакако јесте и те како значајно и с чиме се у потпуности можемо сложити.

\section{ЗАКљУЧАК}

Контрастирање методичких приступа/метода у настави граматике српског и енглеског језика је показало да су и у једном и у другом предмету кроз дуг временски период у практичној настави у примени била традиционално обојена методичка поступања. На тако конципираним часовима инсистирало се на металингвистичком граматичком знању, а занемаривала употреба језика у свакодневним животним ситуацијама. Увођењем у практичну наставу функционалних поступака при усвајању језичких садржаја (од ученика се захтева максимално умно ангажовање, задаци се решавају уз мисаону напрегнутост која укључује различите логичке операције), превазилазе се мане традиционалне наставе и ствара занимљивија и ефикаснија настава језика у којој је у центру пажње ученик и функционално усвајање чињеница о језику и њиховог значења, што је заједничка карактеристика свих помињаних савремених методичких система и у оквиру наставе српског и у оквиру наставе енглеског језика. Сви они свакако имају неке специфичности и управо оне одређују степен самосталности ученика у раду. У том смислу предност увек 
треба давати приступима и методима који ученицима омогућавају интензивно индивидуално умно ангажовање и развој креативних мисаоних процеса, а да, притом, то нимало не штети њиховој култури говора, што значи да на часовима мора да буде присутна расправа и развијен дијалог међу самим ученицима и ученицима и наставником, што потврђују и резултати истраживања. На крају ваља нагласити да је истраживањем, чији су резултати анализирани у овом раду, обухваћен релативно мали узорак, те да би било корисно у будућности на исту тему организовати анкетирање већег броја студената с различитих филолошких факултета те упоредити новодобијене са овде приказаним резултатима.

\section{ЛИТЕРАТУРА}

Благојевић/Кулић 2013: S. Blagojević, D. Kulić, Strani jezik na tercijarnom stepenu obrazovanja, Niš: Filozofski fakultet.

Вилис 1996: J. Willis, A Framework for Task-based Learnig, Harlow: Longman.

Елис 2003: R. Ellis, Second Language Acquisition, Oxford: Oxford University Press.

Илић 1998: П. Илић, Српски језик и књижевност у наставној теорији и пракси. Методика наставе, Нови Сад: Змај.

Клозе 1953: Fr. Closset, Metodika nastave živih jezika, Zagreb: Pedagoško-književni zbor.

Крешен 1987: D. S. Krashen, Principles and Practice in Second Language Acquisition, Englewood Cliffs: Prentice-Hall International.

Мамузић 1965: И. Мамузић, Траженим путем, Београд: Друштво за српскохрватски језик и књижевност СР Србије.

Михајловић 2019: Ј. Михајловић, Проблемски приступ настави граматике у основној школи, Косовска Митровица: Филозофски факултет.

Московищ 1978: G. Moskowitz, Caring and Sharing in the Foreign Language Class: A Sourcebook on Humanistic Techniques, Massachusetts:Heinle \& Heinle Publishers.

Нунан 1997: D. Nunan, Syllabus design, Oxford: Oxford University Press.

Ричардс/Poџерс 1991: J. C. Richards, T. S. Rodgers, Approaches and Methods in Language Teaching, Cambridge: Cambridge University Press.

Росандић 1986: D. Rosandić, Metodika književnog odgoja i obrazovanja, Zagreb: Školska knjiga.

Скривенер 2005: J. Scrivener, Learning Teaching, Oxford: Macmillan Education.

Тежак 1984: S. Težak, Gramatika u osnovnoj školi, Zagreb: Školska knjiga. 
Уp 2000: P. Ur, A Course in Language Teaching, Cambridge: Cambridge University Press. Хармер 1995: J. Harmer, Teaching and Learning Grammar, Harlow: Longman. Хармер 2007: J. Harmer, The Practice od English Language Teaching, Harlow: Longman.

Xeu 2001: T. Hedge, Teaching and Learning in the Language Classroom, Oxford: Oxford Univeristy Press.

\section{APPROACHES TO GRAMMAR IN TEACHING SERBIAN LANGUAGE AS A MOTHER TONGUE AND ENGLISH AS A FOREIGN LANGUAGE}

\section{Summary}

Grammar teaching has always attracted the attention of theoretical experts and practicioners in both mother tongue and foreign language. Unfortunately, there has been a week cooperation between English and mother tongue language teaching methodologists. This paper presents an attempt to get these two issues into contact and observe them from the theoretical and students' perspective. The research subject in this paper is the examination of methodological approaches which have been applied in Serbian language classes, as well as in English language classes, both in primary and secondary schools. Because of the necessity to make difference between traditional and modern grammar teaching, in the first part of the paper, a contrastive analysis of the prevailing methodological approaches in the mother tongue and foreign language teaching, starting from the oldest to the most contemporary, is presented. In the second part of the paper the results of the research, regarding practical application of the methodological approaches that have been conducted among the students of Departments of Serbian language and literature and English language and literature at the Faculty of Philosophy in Kosovska Mitrovica, are shown. Students' attitudes have been based on their experience concerning different grammar teaching approaches they were exposed to during primary and secondary school, as well as their theoretical and practical knowledge they acquired at Methodology language courses which included obligatory visits to nearby schools. The ultimate aim of this paper is to share and adopt positive experiences that are common to each of these two separate, yet similar fields of teaching.

Key words: grammar, methodological approaches, traditional approach, inductive-deductive approach, contemporary teaching approaches. 